\title{
Pengaruh Bauran Pemasaran terhadap Proses Keputusan Pembelian di Rumah Makan Daun Pisang Bandung
}

\author{
Dian Rosita ${ }^{1}$, Agus Sudono $^{1}$, Masharyono ${ }^{2}$ \\ ${ }^{1}$ Manajemen Industri Katering, Fakultas Pendidikan Ilmu Pengetahuan Sosial, Universitas \\ Pendidikan Indonesia, Jl. Dr. Setiabudhi No. 229, Bandung 40154, Indonesia \\ ${ }^{2}$ Manajemen Bisnis, Fakultas Pendidikan Ekonomi dan Bisnis, Universitas Pendidikan \\ Indonesia, Jl. Dr. Setiabudhi No. 229, Bandung 40154, Indonesia
}

* Koresponding Penulis. E-mail: dianrosita@student.upi.edu (Dian Rosita)

\begin{abstract}
Abstrak
Penelitian ini berfokus pada pengaruh bauran pemasaran terhadap proses keputusan pembelian di Rumah Makan Daun Pisang Bandung. Permasalahan yang terjadi dalam penelitian ini adalah penurunan hasil penjualan selama beberapa tahun terakhir, meskipun tahun 2016 mengalami peningkatan namun bisa dibilang peningkatannya sangat sedikit. Tujuan dari penelitian ini adalah untuk mengetahui pengaruh dari bauran pemasaran yang dilakukan oleh Rumah Makan Daun Pisang terhadap proses keputusan pembelian konsumen. Metode yang digunakan dalam penelitian adalah explanatory survey dengan sampel yang berasal dari populasi konsumen Rumah Makan Daun Pisang Bandung. Berdasarkan penelitian yang dilakukan, didapatkan hasil yang menunjukkan bahwa bauran pemasaran berpengaruh positif dan signifikan terhadap proses keputusan pembelian. Saran dalam penelitian ini adalah proses keputusan pembelian dapat ditingkatkan jika pemilik berfokus pada peningkatan program- program promosi yang dari perusahaan, sehingga akan banyak sumber informasi yang diketahui konsumen tentang Rumah Makan Daun Pisang Bandung.
\end{abstract}

Kata Kunci: Bauran Pemasaran; Keputusan; Pembelian

\section{Pendahuluan}

Indonesia merupakan Negara yang tengah berkembang pesat sektor pariwisatanya. Pariwisata merupakan proses perpindahan sementara dari rumah menuju ke tempat lain di luar tempat tinggalnya, bukan dengan tujuan untuk menghasilkan upah melainkan untuk kegiatan yang dirasa dapat memenuhi keinginannya untuk memperoleh kepuasan tersendiri bagi dirinya.

Salah satu provinsi yang tengah emngembangkan sector pariwisatanya adalah Jawa Barat, hal ini trebukti sejak dua tahun lalu yang sempat menjadi perbincangan, karena penghargaan ke-192 yang diberikan Menteri Dalam Negeri
Tjahyo Kumolo kepada Gubernur Jawa Barat Ahmad Heryawan (Aher) dalam Regional Marketing Award 2015 karena berhasil memasarkan potensinya kepada investor. Salah satu faktor penyebabnya adalah pembenahan pariwisata.

Salah satu atraksi wisata yang sangat mendukung pembangunan kepariwisataan adalah usaha kuliner. Pada Provonsi Jawa Barat sendiri usaha kuliner yang paling banyak berkembang berada di Kota juga Kabupaten Bandung. Usaha kuliner di Kota Bandung ini berupa Restoran, Café, Katering, Lesehan, Angkringan, bahkan sampai pedagang kakilima bisa kita jumpai diseluruh Kota Bandung.

Persaingan dalam usaha kuliner sungguhlah sangat ketat, banyak usaha 
kuliner yang gulung tikar dikarenakan banyaknya pesaing baru yang lebih unggul dalam hal kulitas produk maupun pelayanan, dan juga yang lebih modern. Maka pemasaran sangat diperlukan untuk pemenuhan kebutuhan konsumen dengan tetap memperoleh keuntungan bagi perusahaan.

Usaha kuliner menjadi usaha yang menjamur di Kota Bandung, dari sekian banyaknya usaha kuliner di Bandung, ada salah satu tempat usaha yang mampu bertahan dalam persaingan dan cukup populer yakni Rumah Makan Daun Pisang yang terletak di Jl. Setiabudhi No. 154. Rumah Makan ini berdiri sejak tanggal 10 Agustus 1996.

Proses penjualan produk di Rumah Makan Daun Pisang ini tidak hanya menerima pesanan dari tamu yang datang langsung kesana, melainkan juga menyediakan untuk delivery. Menurut keterangan Anton Winoto. S selaku pemilik Rumah Makan, walaupun usaha ini sudah berdiri selama duapuluh tahun, namun penjualannya dari sejak awal hingga kini belum pernah mengalami perubahan yang begitu drastis dan cenderung stagnan.

Berdasarkan penjelasan beberapa hal di atas, maka penulis akan melakukan penelitian dengan judul "Pengaruh Bauran Pemasaran Terhadap Proses Keputusan Pembelian di Rumah Makan Daun Pisang Bandung."

Berdasarkan latar belakang di atas, maka penyusun akan berfokus pada beberapa poin permasalahan yang akan dirumuskan sebagai berikut:
a. Bagaimana gambaran bauran pemasaran di Rumah Makan Daun Pisang Bandung?
b. Bagaimana gambaran proses keputusan pembelian di Rumah Makan Daun Pisang Bandung?
c. Bagaimana pengaruh bauran pemasaran terhadap proseskeputusan pembelian di Rumah Makan Daun Pisang Bandung?
Bauran disebut juga sebagai serangkaian aktivitas dalam manajemen

pemasaran guna mencapai tujuan perusahaan. Beberapa tahun yang lalu aktifitas ini meliputi product, price, place dan promotion. Namun seiring berjalannya waktu bauran pemasaran ini berkembang menjadi konsep yang baru yang terdiri atas people, process, program dan performance.

\section{Metode Penelitian}

Jenis penelitian yang digunakan adalah penelitian deskriptif dan verifikatif. Deskriptif berarti menggambarkan seluruh data yang telah terkumpul kemudian menguji suatu kebenaran hipotesis melalui data dari lapangan dengan menggunakan alat analisis.

Sedangkan proses keputusan pembelian merupakan serangkaian pengalaman tentang mempelajari, memilih, menggunakan atau keputusan untuk tidak menggunakan produk tersebut proses keputusan pembelian ini terbagi kedalam lima tahapan yaitu pengenalan kebutuhan, pencarian informasi, evaluasi alternatif, keputusan pembelian, dan perilaku pasca pembelian.

Metode yang digunakan adalah metode explanatory survey dimana penelitian baik dilakukan pada populasi besar atau kecil tetap yang diambilnya adalah sampel yang menunjukkan kejadian relatif, distribusi dan hubungan antar variabelnya.

\section{Hasil dan Pembahasan}

\section{Rekapitulasi Tanggapan}

responden terhadap bauran pemasaran bertujuan untuk mengetahui pendapat responden sebagai konsumen mengenai bauran pemasaran yang dilakukan oleh Rumah Makan Daun Pisang, untuk lebih jelasnya dapat dilihat dalam tabel berikut ini: 
Tabel 1. Rekapitulasi Tanggapan Responden terhadap Bauran Pemasaran

\begin{tabular}{lllcc} 
No. & Dimensi & $\begin{array}{c}\text { Total } \\
\text { Skor }\end{array}$ & $\begin{array}{c}\text { Skor } \\
\text { Ideal }\end{array}$ & $\begin{array}{c}\text { Persentase } \\
(\%)\end{array}$ \\
\hline 1. & People & 903 & 1134 & 79.6 \\
2. & Process & 891 & 1134 & 78.6 \\
3. & Program & 755 & 1134 & 66.6 \\
4. & Performance & 1370 & 1701 & 80.5 \\
& Total & 3919 & 5103 & 76.8 \\
\hline
\end{tabular}

Sumber : Data diolah, 2017

Berdasarkan Tabel diatas dapat terlihat sekali bahwa bauran pemasaran yang dilakukan sudah terlihat cukup baik menurut responden dengan persentase $76.8 \%$ dari skor idealnya. Dengan dimensi tertinggi terletak pada performance sebagai pendorong paling utama dalam bauran pemasaran dengan skor $80.5 \%(1370 / 1701 \times 100 \%)$ dari skor ideal. Sementara skor terendah dalam bauran pemasaran yang dilakukan Rumah Makan Daun Pisang adalah program dengan skor $66,6 \%(755 / 1134 \times 100 \%)$ dari skor idealnya.

Tanggapan responden sebanyak 81 orang terhadap proses keputusan pembelian bertujuan untuk mengetahui gambaran konsumen Rumah Makan Daun Pisang Bandung dlaam prosesnya ketika membeli produk di Rumah Makan, untuk lebih jelasnya dapat dilihat dalam tabel berikut ini:

Tabel 2. Rekapitulasi Tanggapan Responden terhadap Proses Keputusan Pembelian

\begin{tabular}{|c|c|c|c|c|}
\hline No. & Dimensi & $\begin{array}{l}\text { Total } \\
\text { Skor }\end{array}$ & $\begin{array}{l}\text { Skor } \\
\text { Ideal }\end{array}$ & $(\%)$ \\
\hline 1. & $\begin{array}{l}\text { Pengenalan } \\
\text { Kebutuhan }\end{array}$ & 914 & 1134 & 80.6 \\
\hline 2. & $\begin{array}{l}\text { Pencarian } \\
\text { Informasi }\end{array}$ & 1201 & 1701 & 70.6 \\
\hline 3. & $\begin{array}{l}\text { Evaluasi } \\
\text { Alternatif }\end{array}$ & 874 & 1134 & 77.1 \\
\hline 4. & $\begin{array}{l}\text { Keputusan } \\
\text { Pembelian }\end{array}$ & 1226 & 1701 & 72.1 \\
\hline 5. & $\begin{array}{l}\text { Perilaku Pasca } \\
\text { Pembelian }\end{array}$ & 1703 & 2268 & 75.1 \\
\hline & Total & 5918 & 7938 & 74.5 \\
\hline
\end{tabular}

Berdasarkan Tabel 2 dapat terlihat sekali bahwa proses keputusan pembelian konsumen berlangsung dengan cukup persentase $74.5 \%$ dari skor idealnya.

Dengan dimensi tertinggi terletak pada pengenalan kebutuhan, ini berarti pengenalan kebutuhan adalah dimensi tertinggi yang lebih banyak dipengaruhi oleh bauran pemasaran yaitu dengan persentase $80.6 \%$ dari skor ideal. Sementara skor terendah dalam proses keputusan pembelian adalah pencarian informasi dengan skor $70,6 \%$ dari skor idealnya.

\section{Kesimpulan}

Daun Pisang Bandung berdasarkan hasil penelitian adalah bahwa dimensi yang lebih dominan dilakukan oleh Rumah Makan Daun Pisang Bandung dalam bauran pemasaran adalah performance yaitu dalam hal kebersihan lingkungan, keteraturan tempat duduk dan kerapian seragam karyawan. Sedangkan dimensi yang jarang dilakukan atau rendah adalah berada pada dimensi program yaitu kurang dalam hal desain produk dan potongan harga yang dilakukan Rumah Makan Daun Pisang Bandung.

Gambaran mengenai proses keputusan pembelian di Rumah Makan Daun Pisang Bandung berdasarkan hasil penelitian yang dilakukan adalah bahwa dimensi yang paling banyak dirasakan konsumen dengan nilai tertinggi dalam proses keputusan pembelian adalah pengenalan kebutuhan yaitu adanya pruduk. Sementara yang paling kurang dirasakan adalah pencarian informasi yaitu kurang mendapatkan informasi dari prmosi yang dilakukan Rumah Makan Daun Pisang Bandung karena konsumen yang datang ke Rumah Makan Daun Pisang Bandung mendapatkan informasi dari kerabat terdekat.

Terdapat pengaruh yang signifikan dari bauran pemasaran terhadap proses keputusan pembelian.

Berdasarkan simpulan dari hasil penelitian, ada beberapa rekomendasi untuk meningkatkan proses keputusan pembelian 
yang dapat dipertimbangkan oleh Rumah Makan Daun Pisang Bandung, diantaranya adalah sebagai berikut :

a. Rumah Makan Daun Pisang Bandung lebih meningkatkan aktifitas dalam program yang dilakukannya, hal ini berkaitan dengan simpulan pada dimensi program yang memperoleh nilai terendah dari keseluruhan dimensi. Program atau kegiatan yang dilakukan dapat berupa mengadakan event khusus dari Rumah Makan Daun Pisang dengan masyarakat sekitar sebagai kontributor semisal lomba memasak ketika 17 Agustus. Kemudian bagi konsumen yang datang dari luar kota disediakan potongan harga (diskon) setiap menu dengan syarat menunjukkan kartu identitas berdomisili di luar Kota Bandung.

b. Rumah Makan Daun Pisang harus meningkatkan aktifitas proses keputusan pembelian agar dapat mencapai tujuan perusahaan terutama dalam hal pencarian informasi. Secara keseluruhan proses keputusan pembelian yang dilakukan konsumen Rumah Makan Daun Pisang sudah cukup tinggi, namun masih lemah dalam dimensi pencarian informasi. Sehingga diharapkan Rumah Makan Daun Pisang Bandung dapat meningkatkan program promosinya secara meluas diberbagai media sosial seperti Facebook, Instagram, bahkan membuat Blog tentang Rumah Makan.

c. Rekomendasi untuk penelitian selanjutnya adalah lebih mengembangkan teori mengenai ilmu manajemen pemasaran modern agar dapat disesuaikan dengan perkembangan zaman yaitu dengan memperdalam penelitian mengenai penerapan program di suatu Rumah Makan.

\section{Daftar Pustaka}

Anderson, P. M., \& He, X. (1998). Proce Influence and Age Segments of
Beijing Consumers. Journal of Consumer Marketing, 159.

Ali, M. (1992). Strategi Penelitian Pendidikan dan Strategi. Bandung: Angkasa.

Arikunto, S. (2013). Prosedur Penelitian: Suatu Pendekatan Praktik. Jakarta: Rineka Cipta.

Bagus, D. (2009). Faktor-Faktor yang Mempengaruhi Perilaku Konsumen dalam Pembelian Suatu Produk. Jurnal Manajemen, Bahan Kuliah Manajemen, 6.

Chan, A. (2010). Pengaruh Ekuitas Merek Terhadap Proses Keputusan Pembelian Konsumen: Studi Kasus Bank Muamalat Indonesia Cabang Bandung. Jurnal Administrasi Bisnis, 43.

Fadiati, A. (2013). Mengelola Usaha Jasa Boga yang Sukses. Bandung: Remaja Rosdakarya.

Fathoni, A. (2006). Metodologi Penelitian dan Teknik Penyusunan Skripsi. Jakarta: Rineka Cipta.

Hafsah, M. J. (2015). Upaya Pengembangan Usaha Kecil dan Menengah (UKM). Infokup, 12(25).

Herawati, T., Rudatin, C. L., \& Akbar, D. (2015). Potensi Kota Bnadung Sebagai Destinasi Incentive Melalui Perkembangan Ekonomi Kreatif. Epigram, 11(2).

Hermawan, A. (2012). Komunikasi Pemasaran. Jakarta: Erlangga.

Kotler, P., \& Keller, K. L. (2016). Marketing Manajement. England: Pearson.

Misbahuddin, \& Hasan, I. (2013). Analisis Data Penelitian dengan Statistik. Jakarta: PT Bumi Aksara.

Napompech, K., \& Kuawiriyapan, S. (2011). Factors Affecting the Second Hand Clothes Buying Decision of Thai Women. Internarltional Journal of Arts and Sciences, 207.

Pitana, I. G. (2009). Pengantar Ilmu Pariwisata. Bandung: Andi.

Rasyid, H. A. (1994). Teknik Penarikan Sampel dan Padjadjaran. 
Park, C.-H., \& Kim, Y.-G. (2003). Identifying Key Factors Affecting Consumer Purchase Behavior in an Online Shopping Context. Emerald: International Journal of Retail and Distribution Management, 25.

Perpustakaan Nasional. (2016,

Oktober 13). Diambil

kembali dari Kepustakaan Presiden : http://kepustakaan-

presiden.perpusnas.go.id/government _regulation/?box=list_245\&search_je nis $=U U \&$ presiden $\_\mathrm{id}=6 \&$ presiden $=\mathrm{s}$ by

Penyusunan Skala. Bandung: Universitas Setiadi, N. J. (2015). Perilaku Konsumen: .Jakarta: Prenadamedia Group.

Petra. (2013). Penyusunan Strategi dan Sistem Penjualan dalam Rangka Meningkatkan Penjualan Toko Damai. 2(1).

Raharjani, J. (2005). Analisis Faktor- Faktor yang Mempengaruhi Keputusan Peilihan Pasar Swalayan Sebagai tempat berbelanja. jurnal studi majemen dan organisasi, 3 .

Rao, A. R., \& Monroe, K. B. (1989). The Effect of Price, Brand name, and Store Name on Buyers' Perceptions of Product Quality: An Integrative Review. Journal of Marketing Research, 356.

Rasyid, D. A. (2015, Desember 11). Gubernur Jabar Terima Penghargaan Ke-192. Jurnal Priangan, hal. 1.

Rasyid, D. A. (2016, Januari 7). Pertumbuhan Ekonomi Jabar Meningkat di Tahun 2016. Jurnal Priangan, hal. 1.

Razati, G., Sumiyati, \& Masharyono. (2016). Analysis Factor Affecting Students' Satisfaction with Academic Services Based on Servqual. Atlantis Press, 270.

Senen, S. H., Sumiyati, \& Masharyono. (2016). The Effect of Skill Variety, Task Identity, Task Sigificance, Autonomy and Feedback on Job
Performance. Atlantis Press, 585.

Soemanto, R. (2010). Sosiologi Pariwisata. zSOSI4415/MODUL 1, 15.

Sudrajat, A. (2017, Januari Jumat). Jawa Barat dikunjungi 46.1 juta wisatawan pada 2016. Antara News, hal. 1.

Sugiyono. (2010). Metode Penelitian Bisnis. Bandung: Alfabeta.

Sugiyono. (2015). Metode Penelitian Pendidikan. Bandung: Alfabeta.

Sugiyono. (2016). Metode Penelitian \& Pengembangan: Resaearch and development. Bandung: Alfabeta.

Sukotjo, H., \& Radix, S. (2010). Analisa Marketing Mix-7p (Product, Price, promotion, Place, Partisipant, Process, dan Physical Evidence) terhadap Keputusan Pembelian Produk Klinik Kecantikan Teta di Surabaya. Mitra Ekonomi dan Manajemen Bisnis, 217.

Suwantoro, G. (2004). Dasar-Dasar Pariwisata. Yogyakarta: Andi.

Suwarman, U. (2004). Perilaku Konsumen: Teori dan Penerapannya dalam Pemasaran . Bogor: Ghalia Indonesia.

Umar, H. (2008). Metode Penelitian untuk Skripsi dan Tesis Bisnis. Jakarta: PT Rajagrafindo Persada.

Utama, I. G. (2014). Pengantar Industri Pariwisata: Tantangan dan Peluang Bisnis Kreatif. Yogyakarta: Deepublish.

Wood, R. C. (2013). Key Concepts in Hospitality Management. Los Angeles: Sage.

Yoeti, O. A. (2013). Pemasaran Pariwisata. Bandung: Angkasa. 